\title{
INFLUENCE OF MANUFACTURER SIGNATURE ON STORE BRANDS' LOYALTY AND PURCHASE INTENTION
}

\author{
Influência da assinatura do fabricante na lealdade e intenção de compra de \\ marcas próprias de varejista \\ Influencia de la firma del fabricante sobre la lealtad a las marcas blancas y la \\ intención de compra
}

\begin{abstract}
With today's trend toward higher store concentration, building strong store brands has become a priority for many retailing companies. This study aims to analyze the differences in store brands' purchasing likelihood between store brands with a manufacturer identification - a manufacturer signature - and store brands with no information about the manufacturer, as well as the moderating role of the manufacturer signature on store brands' purchase intention. We carried out multiple group analysis through structural equation modeling. Our findings suggest that store brand image has the most significant influence on loyalty and purchase intention for both types of store brands. Moreover, and contrary to our expectations, we did not find empirical support for the moderating role of manufacturer signature on store brands' purchasing likelihood.
\end{abstract}

KEYWORDS | Store brand, purchase intention, loyalty, manufacturer, retailer.

\section{RESUMO}

Com a atual tendência a uma maior concentração das lojas, a construção de marcas próprias de varejista tornou-se uma prioridade para muitas empresas de varejo. O presente estudo destina-se a analisar as diferenças de propensão à compra de marcas próprias entre marcas próprias com identificação de fabricante - assinatura do fabricante - e marcas próprias sem informações sobre o fabricante, bem como o papel moderador da assinatura do fabricante na intenção de compra de marcas próprias. Realizamos análises multigrupo através da modelagem de equações estruturais. Nossos achados sugerem que a imagem da marca própria exerce a influência mais significativa sobre a lealdade e a intenção de compra para ambos os tipos de marcas próprias. Ademais, e contrariamente a nossas expectativas, não encontramos apoio empírico para o efeito moderador do papel da assinatura do fabricante na propensão à compra de marcas próprias de varejistas.

ccalvo@udc.es

Professor at Universidade da Coruña, Facultad de Economía y Empresa-

Coruña, Spain

\section{VALENTÍN-ALEJANDRO MARTÍNEZ- FERNÁNDEZ}

valejand@udc.es

Professor at Universidade da Coruña,

Facultad de Economía y Empresa-

Coruña, Spain

\section{OSCAR JUANATEY-BOGA}

oscarjb@udc.es

Professor at Universidade da Coruña,

Facultad de Economía y Empresa-

Coruña, Spain

\section{RESUMEN}

Debido a la tendencia actual hacia la mayor concentración en la distribución, la construcción de marcas fuertes del distribuidor se ha convertido en una prioridad para muchas empresas de distribución. Este estudio trata de analizar las diferencias en la predisposición a comprar marcas del distribuidor, entre aquellas con identificación del fabricante -firma del fabricante-y aquellas otras que no ofrecen información sobre el fabricante del producto; así como analizar el papel moderador de la firma del fabricante en su intención de compra. Se llevó a cabo un análisis multigrupo mediante un modelo de ecuaciones estructurales. Nuestros resultados sugieren que la imagen ejerce la mayor influencia sobre la lealtad y la intención de compra de ambos tipos de marca del distribuidor. Además, y contrariamente a nuestras suposiciones, no hallamos suficiente evidencia empírica para confirmar el papel moderador de la firma del fabricante en la predisposición a comprar marcas del distribuidor. PALABRAS CLAVE / Marca del distribuidor, intención de compra, lealtad, fabricante, distribuidor. 


\section{INTRODUCTION}

With today's trend toward retailing internationalization, higher store concentration, global recession, and changing consumer habits, building strong retailer brands has become a marketing priority for many retailing companies (Ailawadi \& Keller, 2004; Anselmsson, Johansson, \& Persson, 2007). Industry reports confirm that the market share of store brands have risen around the world in the last decades, reaching significant levels across Europe and North America (Kumar \& Steenkamp, 2007; Manzur, Olavarrieta, Hidalgo, Farías, \& Uribe, 2011). Store brands, termed also private brands, retailer brands, wholesale brands, and distributor's brands, are brands developed and managed by retailers (Ailawadi \& Keller, 2004; Bao, Bao \& Sheng, 2011) which have been increasingly attracting the interest of managers and marketing scholars, in parallel with their increasing market share (Karry \& Zaccour, 2006) There are many incentives for retailers to create and manage store brands, such as increasing customer loyalty, retailer performance, profit margins, and a high value offering in the marketplace (Corstjens \& Lal, 2000; Diallo, 2012; Sudhir \& Talukdar, 2004).

Although store brands seem to offer a better price-quality relationship than manufacturer brands, they are targeting and meeting a specific consumer demand with a particular offer, pricing, and packaging (Ailawadi \& Keller, 2004). Although previous literature has stressed that store brands' competitiveness comes mainly from lower prices and less promotional expenses (Bao, Bao, \& Sheng, 2011), many authors now note that store brands offer quality levels similar to manufacturer brands (Grewal \& Levy, 2009).

The present study aims to provide a more in-depth understanding of the variables influencing store brands' loyalty and purchase intention, as well as an assessment of the influence of manufacturer signature - that is, an identification of the manufacturer on the package - on purchase intention. More specifically, the main contribution we expect to make with this study is threefold. First, the aim of the study is to investigate the influence of manufacturer signature on consumers' store brand loyalty and purchase intention. For this purpose, we will evaluate the impact of manufacturer identification on store brands' packages - the so-called manufacturer signature - since previous research has demonstrated the major importance of perceived risk on store brands purchase behavior (Diallo, 2012; Liljander, Polsa, \& Riel, 2009), although little is known about the influence of manufacturer identification. Second, we attempt to examine the influence of store image, store brands' perceived quality, and store brands' image on consumers' behavioral intentions. Finally, we analyze the mediating influence of store brand loyalty on the relationships considered in our proposed conceptual model. Our study provides some interesting insights for retail managers, since shedding light on consumer behavior towards store-branded products allows a better understanding of the retailing market. This paper is structured as follows. In the first section we develop a conceptual framework based on the intangible attributes of store brands. This is followed by a description of both the methodology adopted and the fieldwork. Subsequently, results are presented and discussed. Finally, major conclusions and some managerial implications are provided.

\section{CONCEPTUAL FRAMEWORK}

\section{Store brands' positioning and manufacturer signature}

Price plays an essential role in the configuration of store brands' proposition (Richardson, Jain, \& Dick, 1996), since store brands are characterized by a low-price positioning that comes from consumers' perceiving store brands as a convenient price option compared to manufacturer brands (Ailawadi, Pauwels, \& Steenkamp, 2008). Store brands' initial positioning was based on offering consumers a competitive price as an alternative to manufacturer brands, helping retailers to compete in the pricesensitive segment (Corstjens \& Lal, 2000). Purchasers of store brands are generally value-conscious (Bao et al., 2011) and tend to seek low prices for a certain quality, i.e., they do not purchase store brands because they are cheap, but rather because such brands are good value for money (Hoch \& Banerji, 1993). However, recently, store brands have been developed with a stronger orientation towards quality, offering a value proposition similar to manufacturer brands (Hoch \& Banerji, 1993).

In addition, different types of store brands are available in the marketplace: some retailers do not delete the manufacturer information from the product package, which allows manufacturer recognition; while other retailers do not provide information about the manufacturer of their store brand products. More specifically, the term manufacturer signature (Inman, Shankar, \& Ferraro, 2004) refers, in the present study, to the manufacturer identification on the package of a store brand product. Therefore, store brands may or may not identify a particular product manufacturer (Huang \& Huddleston, 2009). Following Choi and Huddleston (2013), consumers hold a favorable, strong quality perception toward store brands when the manufacturer's name is present. As prior research suggests, both store image and product signature induce positive evaluations on consumers (Bao et al., 2011). Additionally, according to Semeijn, Riel, and Ambrosini (2004), store image acts as a risk reliever and positively influences consumers' evaluations of storebranded products. Consequently, the presence of a manufacturer signature or identification on a store brand product creates a strong 
association or link between the product manufacturer and the store brand, reducing purchase risk (Bao et al., 2011). Moreover, the store brand with a manufacturer signature sends a strong signal to consumers about the product quality and image, perceptually carrying a lower purchase risk (Bao et al., 2011; Batra \& Sinha, 2000) compared with store brands with no manufacturer signature.

That is, the manufacturer's name and reputation are directly linked to the store brand product. Consequently, the present study proposes that consumers would have more favorable perceptions and a stronger purchase intention towards those store brands with a manufacturer identification, considering that consumers will prefer the guarantee of a familiar manufacturer, rather than the risks linked with purchasing an unknown manufacturer product (Baltas, 1997). In this vein, our study maintains that a cue the retailer could employ to influence store brands' purchase intention is manufacturer signature.

\section{Research questions and hypotheses}

The present study aims to analyze how store brands' loyalty and purchase intention are formed. To this end, we compare store brands with a manufacturer signature - that is, with a manufacturer identification on the package - and store brands lacking that information. More specifically, we pose one major research question: "What are the influences of store and brand image on customer loyalty and purchase intention in the case of store brands with a manufacturer signature, and in the case of store brands without a manufacturer signature?".

\section{The mediating role of store brand loyalty}

One of the goals of the this study is to examine the mediating role of store brand loyalty and its influence on purchase intention. According to previous research, store brand loyalty is influenced both by a store brand's favorable image (Steenkamp \& Dekimpe, 1997) and by a store brand's perceived quality (Choi \& Huddleston, 2013). However, not only does empirical evidence exists of the relationship between store brand image, perceived quality, loyalty, and purchase intentions (Huang \& Huddleston, 2009), but also it has been demonstrated that store brand loyalty mediates the relationship between image, perceived quality, and the purchase intention (Huang \& Huddleston, 2009).

\section{Store image}

In the present study, the authors consider that store image is expressed in terms of a store's attributes as assessed by consumers (Devlin, Birtwistle, \& Macedo, 2003). Moreover, following Beristain and Zorrilla (2011), we assume two key dimensions of store image, namely store commercial image and store social image.

\section{Store commercial image}

Store image refers to the consumer's global impression of a retail store (Zimmer \& Golden, 1988), and it is one of the main sources of store value (Hartman \& Spiro, 2005). Ailawadi and Keller (2004) define store image as the retailer's image in the mind of the consumer. According to Diallo (2012), store image develops based on consumers' perceptions learned over time. In this vein, retailer image is a key source of store value, and distributing a brand through an outlet with a good image will create a more favorable image than distributing it through an outlet with a bad image (Zeithaml, 1988). Previous research has demonstrated that store image perceptions positively influence store brand purchase intention (Liljander et al., 2009). In addition, previous studies have demonstrated that store associations and evaluations can be generalized to store brands (Beristain \& Zorrilla, 2011; Collins-Dodd \& Lindley, 2003; Vahie \& Paswan, 2006).

On the other hand, store commercial image has generally been conceptualized as the way in which the store is defined in the consumer's mind by functional attributes such as the quality of products offered, product assortment, services provided to customers, physical facilities and layout, internal environment, and good value-for-money relationship (Anselmsson et al., 2007; Chowdhury, Reardon, \& Srivastava, 1998). Therefore, we propose the following hypothesis:

$H_{1:}$ Store commercial image has a positive influence on store brand image.

Previous research has found that store image can have significant positive effects on perceived quality (Dodds, Monroe, \& Grewall, 1991), and that retailer commercial image allows consumers to infer the quality of the merchandise (Bao et al., 2011). As a result, consumers perceive a store brand owned by a store with a good image to carry higher quality than a brand from a store with a poor image (Bao et al., 2011); and a favorable store image will have a positive impact on consumers' behavior towards the brand (Yu \& Ramanathan, 2012). Moreover, previous research shows that store image can be determining to product quality (Smeijn et al., 2004). Therefore, because store image perceptions provide a relevant cue for store brands, we should assume that store image provides a basis for overall store brand perceived quality. This means that the quality of a given brand is perceived differently depending on which retailer offers it. Thus, we propose the following hypothesis: 
$\mathrm{H}_{2:}$ Store commercial image has a positive influence on store brand perceived quality.

Previous research has also demonstrated that store image perceptions can positively influence store brand purchase intention (Diallo, 2012; Liljander et al., 2009; Vahie \& Paswan 2006). Thus, we propose the following research hypothesis:

$\mathrm{H}_{3}$ : Store commercial image has a positive influence on store brand purchase intention.

\section{Store social image}

Store social image is conceptualized as the store's attributes as perceived and assessed by consumers (Devlin et al., 2003). According to Turban and Greenging (1996) and Brown and Dacing (1997), consumers perceive a company by evaluating aspects such as the company's behavior and commitment to society (Higgins \& Bannister, 1992). In this vein, Keller and Aaker (1992) highlighted the key role of innovation capacity, which influenced both the perceived quality and purchase intention of brands identified with the store's name. Finally, Beristain and Zorrilla (2011) posited that consumers who perceive a store as a competent firm, with know-how and experience, may also perceive it as developing high-quality own brands.

Accordingly, when consumers choose a store brand, they are influenced partly by the retailer's social reputation and image (Choi \& Huddleston, 2013). More specifically, stores can be perceived as companies, whereby store image can be linked to aspects such social interest and commitment, and global corporate strategy (Beristain \& Zorrilla, 2011). In the present study, we assume the social image of a store to derive from its social behavior and corporate background (Schmidt, 1995). Consequently, a store's social image has a positive influence on both the image and the purchase intention of its store brand (Anselmsson et al., 2007; Beristain \& Zorrilla, 2011). The following hypotheses are thus proposed:

$\mathrm{H}_{4:}$ Store social image has a positive influence on store brand image.

$\mathrm{H}_{5 \text { : }}$ Store social image has a positive influence on store brand perceived quality.

$\mathrm{H}_{6}$ : Store social image has a positive influence on store brand purchase intention.

\section{Store brand image}

Store brand associations or image
Aaker (1991) defines brand associations - or image - as the information in the consumer's mind linked to the brand that creates favorable attitudes towards the brand. According to Yoo, Donthu, and Lee (2000), brand associations consist of multiple images, ideas, instances, or facts that establish a solid network of brand knowledge, resulting in a higher purchase intention. Following Beristain and Zorrilla (2011), store brand associations are related to a certain type of consumer, as purchasing products or brands with a good value-for-money relationship lead to a smart buyer impression, and store brands offer a better price-quality relationship than manufacturer brands, thus leading to store brand loyalty and purchase intention (Martos-Partal \& GonzálezBenito, 2011). Therefore, the following research hypotheses are proposed:

$\mathrm{H}_{7:}$ Store brand image has a positive influence on store brand loyalty.

$\mathrm{H}_{8:}$ Store brand image has a positive influence on store brand purchase intention.

\section{Store brand perceived quality}

According to Zeithaml (1988), perceived quality is conceptualized as consumers' global judgment of a brand or product overall excellence or superiority. Perceived quality is also related to consumers' subjective perception of a product or brand attributes, and it constitutes a core brand value, as it is related with brand purchase and brand choice (Aaker, 1991). Following Bao et al. (2011), perceived quality is an intangible attribute specific to a product category or a brand name in the marketplace.

Pappu, Quester, and Cooksey (2005) demonstrated that the higher the quality consumers perceive in a brand, the more likely they are to be loyal to it. Furthermore, the outcome of consumer's associations and perceived quality can result in loyalty to a specific store brand (Choi \& Huddleston, 2013). Consequently, we hypothesize the following:

$\mathrm{H}_{9}$ : Store brand perceived quality has a positive influence on store brand loyalty.

Quality is one of the main determinants of brand purchase, and, additionally, quality perception is positively related with store brand purchase intention (Grewal, Krishnan, Baker, \& Borin, 1998; Richardson et al., 1996). Perceived quality is so important that it can be dominant in determining consumers' intention to purchase store brands (Jin \& Suh, 2005; Bao et al., 2011). Therefore, the present research anticipates that store brand perceived quality will influence purchase intention: 
$H_{10}$ Store brand perceived quality has a positive influence on store brand purchase intention.

Store brand loyalty and purchase intention

According to Jacoby (1971), loyalty should be studied as a behavior, with emphasis on the fact that loyalty also has an attitudinal component, present in the loyalty process. Moreover, Dick and Basu (1994) define loyalty as the relationship between the relative attitude toward a brand, product, or service and a patronage behavior. For this reason, the present study evaluates both attitudinal and behavioral components of loyalty. Later, Oliver (1999) defines brand loyalty as a deeply held commitment to rebuy or repatronize a preferred product or service consistently in the future, despite situational influences, showing a strong influence on purchase intention. According to Aaker (1991) brand loyalty reflects how likely a customer is to switch to another brand, especially when that brand undergoes a change, either in price or features. Myers (2003) remarked a positive significant relationship between the dimensions of store brand loyalty, brand preference, and purchase intention. Following Diallo (2012), the purchase intention could be conceptualized as the consumer's tendency to purchase a brand routinely and resist switching to other competing brands. In the present study, we refer to the purchase intention in order to operationalize the consumer purchase behavior toward store brands. Thus, this set of considerations leads us to propose this research hypothesis:

$H_{11:}$ Store brand loyalty has a positive influence on purchase intention.

Following these theoretical considerations, we propose a model of formation of store brand loyalty and purchase intention as shown in Figure 1.

Figure 1. Proposed Conceptual Model 1

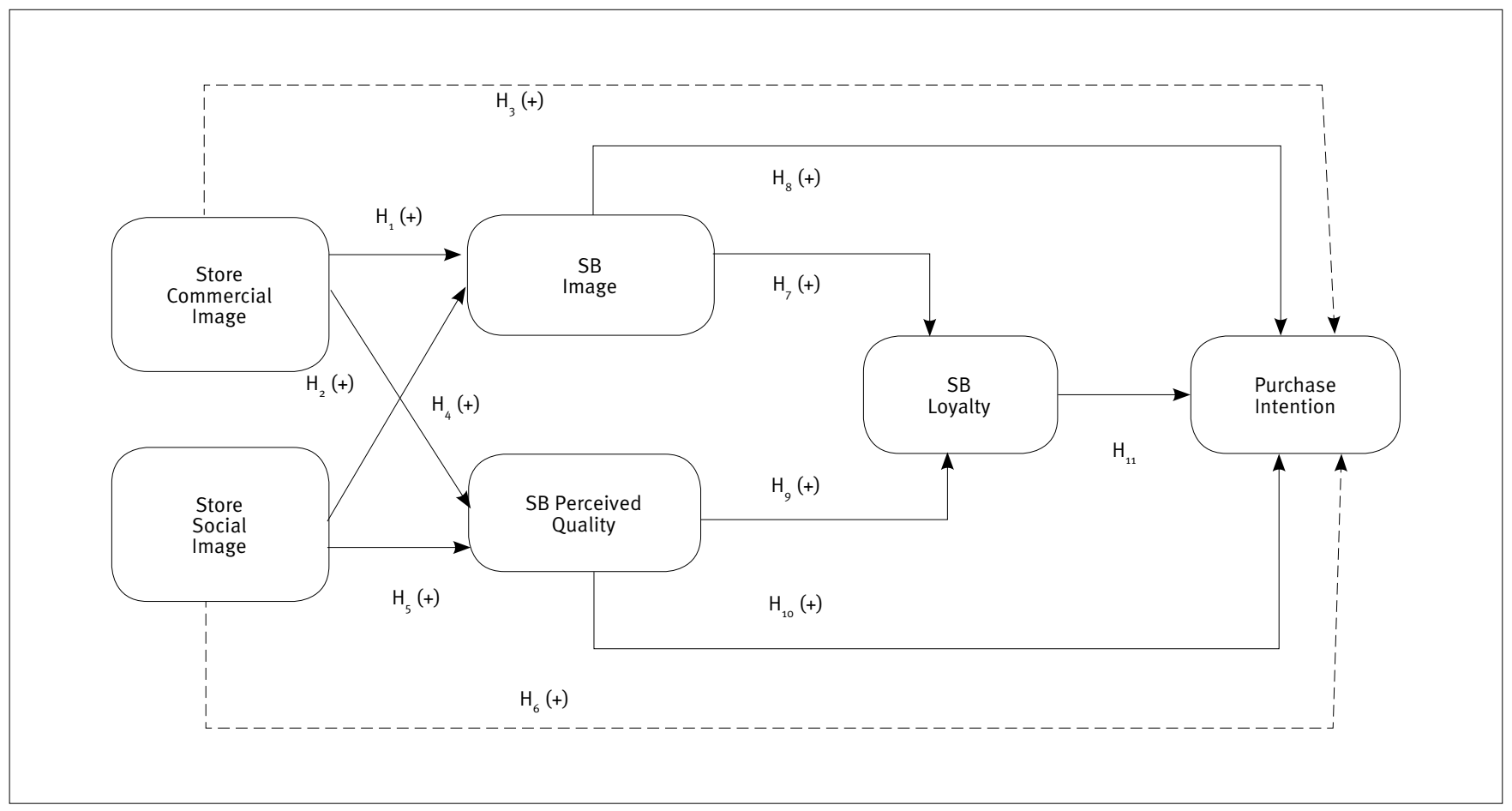

\section{METHOD}

\section{Data collection}

To test the hypotheses, information was collected through a structured online questionnaire, and fieldwork was conducted in March 2012. The sample was chosen randomly from a set of databases of higher education students, public sector employees, and 
employees at small and medium size companies, all of whom were consumers residing in Spain. More specifically, we invited them to complete the online questionnaire, which included some information about the study. The questionnaires evaluated a particular store brand, and five different types of questionnaires were prepared, each type covering the store brand of one of the five major retailers in Spain - Carrefour, Mercadona, El Corte Inglés, Dia, and Eroski - while considering different retailing formats. We deliberately did not ask participants to select the store brand they had knowledge of or consumer experience with; each respondent was given a single questionnaire randomly chosen, and told that even if he/she had never shopped in that particular store, he/she would have perceptions or beliefs about the store's image or the store brand's quality or image. Finally, a sample of 374 consumers was gathered, totaling 326 valid responses (Eroski $=77$, Carrefour $=74$, El Corte Inglés $=74$, Dia $=67$ and Mercadona $=69$ ). Sampling error was $5.53 \%$, with a confidence level of $95 \%$ under the hypothesis $p=q=0.5$.

The last part of the questionnaire contained several sociodemographic questions. With regard to sample profile, $36.1 \%$ of the respondents were aged from 31 to 45 , while $32.8 \%$ were aged 46 to 60 . A total $65.68 \%$ of the respondents were female. In terms of education level, over $38 \%$ of the participants had completed secondary education, while $17.5 \%$ had a higher education degree. Data also indicated that all of the respondents were frequent store brand purchasers, as the majority indicated purchasing store brands every week (44.7\%) and $21.4 \%$ of the participants purchased store brands every fifteen days.

\section{Variables and measurement scales}

We followed two criteria in order to select the retailers for this study. Firstly, we considered Spain's major retailers by total revenue in 2012 (Worldpanel Distribución, 2012). Secondly, we took into account retailers that named their store brands with their own names, including either the store name or logo on the packaging, except for Mercadona, which was selected due to its revenue alone, although its store brand name is not the same as the store's, i.e., its store brands are called Hacendado, Bosque Verde, and Deliplus. Thus, we selected five major popular retailers - Carrefour, Mercadona, Dia, Eroski, and El Corte Inglés. These store brands have a different manufacturer identification on their package. More precisely, the store brands of Mercadona, Eroski, and El Corte Inglés $(n=219)$ identify the manufacturer of their store brand products in all product categories, so these store brands are considered manufacturer signature products, i.e., the products' manufacturers are informed on the packages. On the other hand, the store brands of Carrefour and Dia $(n=143)$ exhibit no manufacturer identification on the packaging, providing only their social identification code number.

All measures were adapted from, or developed based on, prior research, and a classic Likert-type 1-5 scale was used. Store commercial image was measured using three items adopted from Chowdhury et al. (1998) and Beristain and Zorrilla (2011) in order to assess consumers' perception of the store from multiple perspectives, such as product offer, service, and quality. Secondly, we used three items to measure store social image, which we adopted from previous studies (Handelman \& Arnold, 1999) about the influence of company experience and innovation on consumers' perceptions. Store brand image was measured on a 3-item scale comprising the items proposed by Aaker (1991) and Netemeyer et al. (2004). Store brands quality perception was measured with the scale proposed by Doods et al. (1991), which assesses how the consumer globally evaluates the quality of a product or brand. To measure store brand loyalty, we used two items proposed by Yoo et al. (2000) to determine whether the consumer is considered loyal to a particular brand. Finally, purchase intention was measured on a 2 -item scale that includes items adopted from Netemeyer et al. (2004). Therefore, a brief literature review was used to establish the conceptual framework and the variables used in our research (Table 1).

\section{RESULTS}

\section{Analysis of the measurement model}

Following Anderson and Gerbing's (1988) methodological proposal, the data analysis adopts a two-step approach. The first stage involves assessing the measurement model, and the second stage proceeds to test the structural relationships and research hypotheses among the constructs. Structural equation model was carried out with Amos 18.0 in order to analyze the proposed model, using maximum likelihood estimation, thus providing a confirmatory factor analysis (CFA) to test the overall fit of the measurement model. For this model, the comparative fit index (CFI), root mean square error of approximation (RMSEA), Tucker-Lewis Index (TLI), and root mean square residual (RMR) all complied with the threshold levels according to Hair et al. (1999). All of the obtained fit measures indicated that the structural model was acceptable $\left(X^{2} / d f=3.094 ; p<0.000\right): R M S E A=0.054$; RMR $=0.041 ; \mathrm{TLI}=0.959$; and $\mathrm{CFI}=0.972$ ).

Second, in order to examine the reliability, convergent validity, and discriminant validity of the measurement model, Cronbach Alpha, composite reliability coefficients (CR), and average variance extracted (AVE) were calculated for all 
constructs, following Anderson and Gerbing (1988). With regard to reliability, we obtained Cronbach Alpha values from 0.622 to 0.925 (Table 2), which is acceptable according to Anderson and Gerbing (1988) and Hair, Anderson, Tatham, and Black (1999). As a result, 13 items were retained for six constructs in the study, with all the constructs meeting the reliability level of 0.6 . Then, composite reliability values (CR) were calculated, reaching the recommended level of 0.50 , indicating that all measures had good reliability (Baggozi \& Yi, 1988; Hair et al., 1999). Moreover, average variance extracted (AVE) was used to measure convergent validity. All constructs had values higher than the suggested 0.5 threshold, suggesting the convergent validity of the scale (Fornell \& Larcker, 1981). All the completely standardized factor loadings reached the level of significance, with a reliability level of $95 \%$, and reached the 0.50 threshold, thus supporting a strong convergent validity (Fornell \& Larcker, 1981; Steenkamp \& Trijp, 1991).

\section{Table 1. Variables and measurement scales}

\begin{tabular}{|c|c|}
\hline Constructs & Indicators \\
\hline Store commercial image & Colm 1 Store $X$ offers high quality products \\
\hline Chowdhury et al. (1998), Beristain and Zorrilla (2011) & Colm 2 The store X offers services I'm looking for (ex. Pay over time, product return, etc.) \\
\hline Store social image & Solm 1 Store $X$ has a long experience in retailing \\
\hline Handelman and Arnold (1999). & Solm $2 \mathrm{X}$ makes efforts to introduce new products and services to the market \\
\hline SB image & Aso 1 I associate products of store brand X with positive characteristics (ex. good prices) \\
\hline Aaker (1991), Netemeyer et al. (2004) & Aso 2 Customers of products of store brand X know how to buy (purchasing with common sense) \\
\hline \multirow{3}{*}{$\begin{array}{l}\text { SB perceived quality } \\
\text { Doods et al. (1991) }\end{array}$} & Qal 1The products of store brand $\mathrm{X}$ are high quality products \\
\hline & Qal 2 The products of store brand $X$ are reliable/trustworthy \\
\hline & Qal 3 The products of store brand $X$ give me the result I am looking for \\
\hline SB loyalty & Loy1 I consider myself a consumer loyal to store brand X's products \\
\hline Yoo et al. (2000) & Loy2 I will keep on buying store brand X. \\
\hline SB purchase intention & PInt1 I would buy store brand X. \\
\hline Netemeyer et al. (2004) & PInt2 I am likely to buy store brand $X$. \\
\hline
\end{tabular}

Table 2. Factor loadings of latent variables and indicators of internal consistency and reliability

\begin{tabular}{|c|c|c|c|c|c|c|c|c|}
\hline \multirow{2}{*}{ Constructs } & \multirow{2}{*}{ Items } & \multirow{2}{*}{$\begin{array}{c}\text { Cronbach } \\
\text { Alpha }\end{array}$} & \multicolumn{3}{|c|}{ WITH a manufacturer signature } & \multicolumn{3}{|c|}{ NO manufacturer signature } \\
\hline & & & Lambda & CR & AVE & Lambda & CR & AVE \\
\hline $\begin{array}{l}\text { Store commercial } \\
\text { image }\end{array}$ & $\begin{array}{l}\text { Colm1 } \\
\text { Colm2 }\end{array}$ & 0.746 & $\begin{array}{l}0.615 \\
0.872\end{array}$ & 0.695 & 0.549 & $\begin{array}{l}0.643 \\
0.839\end{array}$ & 0.687 & 0.528 \\
\hline Store social image & $\begin{array}{l}\text { Solm1 } \\
\text { Solm2 }\end{array}$ & 0.622 & $\begin{array}{l}0.638 \\
0.667\end{array}$ & 0.573 & 0.511 & $\begin{array}{l}0.619 \\
0.550\end{array}$ & 0.517 & 0.503 \\
\hline SB image & $\begin{array}{l}\text { Aso1 } \\
\text { Aso2 }\end{array}$ & 0.698 & $\begin{array}{l}0.740 \\
0.832\end{array}$ & 0.765 & 0.620 & $\begin{array}{l}0.679 \\
0.855\end{array}$ & 0.716 & 0.581 \\
\hline $\begin{array}{l}\text { SB perceived } \\
\text { quality }\end{array}$ & $\begin{array}{l}\text { Qal1 } \\
\text { Qal2 } \\
\text { Qal3 }\end{array}$ & 0.870 & $\begin{array}{l}0.813 \\
0.874 \\
0.831\end{array}$ & 0.878 & 0.706 & $\begin{array}{l}0.833 \\
0.858 \\
0.712\end{array}$ & 0.844 & 0.645 \\
\hline SB loyalty & $\begin{array}{l}\text { Loy1 } \\
\text { Loy2 }\end{array}$ & 0.861 & $\begin{array}{l}0.918 \\
0.881\end{array}$ & 0.895 & 0.809 & $\begin{array}{l}0.849 \\
0.788\end{array}$ & 0.803 & 0.671 \\
\hline $\begin{array}{l}\text { SB purchase } \\
\text { Intention }\end{array}$ & $\begin{array}{l}\text { Plnt1 } \\
\text { PInt2 }\end{array}$ & 0.925 & $\begin{array}{l}0.936 \\
0.947\end{array}$ & 0.936 & 0.886 & $\begin{array}{l}0.842 \\
0.989\end{array}$ & 0.915 & 0.843 \\
\hline
\end{tabular}


Finally, the discriminant validity of the scale was examined for all possible paired combinations of constructs. Correlation coefficients were calculated both for store brands with a manufacturer signature (Table 3) and store brands without it (Table 4), with strength ranging from low (0.245) to high (0.701), and significant at the 0.05 level. Each latent variable's AVE was larger than the squared correlation between each pair of latent variables, thus demonstrating the good discriminant validity of the scale (Fornell \& Larcker, 1981).

Table 3. Correlations between constructs for store brands with a manufacturer identification

\begin{tabular}{|c|c|c|c|c|c|c|}
\hline & $\begin{array}{c}\text { Store } \\
\text { commercial } \\
\text { image }\end{array}$ & $\begin{array}{l}\text { Store social } \\
\text { image }\end{array}$ & SB image & $\begin{array}{l}\text { SB perceived } \\
\text { quality }\end{array}$ & SB loyalty & $\begin{array}{c}\text { SB purchase } \\
\text { intention }\end{array}$ \\
\hline Store social image & 0.663 & 1 & & & & \\
\hline SB loyalty & 0.701 & 0.633 & 0.606 & 0.653 & 1 & \\
\hline SB purchase intention & 0.578 & 0.637 & 0.624 & 0.603 & 0.680 & 1 \\
\hline
\end{tabular}

Table 4. Correlations between constructs for store brands with no manufacturer identification

\begin{tabular}{l|c|c|c|c|c}
\hline & $\begin{array}{c}\text { Store } \\
\text { commercial } \\
\text { image }\end{array}$ & $\begin{array}{c}\text { Store social } \\
\text { image }\end{array}$ & SB image & $\begin{array}{c}\text { SB perceived } \\
\text { quality }\end{array}$ & $\begin{array}{c}\text { SB purchase } \\
\text { intention }\end{array}$ \\
\hline Store commercial image & 1 & & & & \\
\hline Store social image & 0.647 & 1 & 1 & & \\
\hline SB image & 0.460 & 0.651 & 0.705 & 0.610 & 1 \\
\hline SB perceived Quality & 0.611 & 0.588 & 0.632 & 0.470 & 0.695 \\
\hline SB loyalty & 0.473 & 0.2535 & 0.370 & 0.621 & 1 \\
\hline SB purchase intention & 0.25 & & 1 \\
\hline
\end{tabular}

To test the models' similarity across both groups - store brands with a manufacturer signature and store brands with no manufacturer signature - we conducted multi-group measurement invariance models: configural invariance and metric invariance (Steenkamp \& Baumgartner, 1998). The metric invariance test provides support to the similar use of rating scales with respondents across both groups, so the differences between values can be compared directly. Consequently, by comparing a restricted multiple group model with an unrestricted one, metric invariance assesses the extent to which factor loading estimates are equivalent across groups. The logic is the following: if a set of constraints is applied to a model and model fit does not show a significant increase (meaning worse fit from a less constrained model), then the constraints can be accepted (Hair, Anderson,
Tatham, \& Black, 1998). Following Satorra and Bentler (2001), both models were compared with a Chi-square difference test. Firstly, we calculated a non-restricted model in which the factor loadings of the six constructs were relaxed to vary across the two groups - i.e., store brands with a manufacturer signature and store brands without it; then, the equality of factor loadings between the two groups was assessed - the full-metric invariance model (Steenkamp \& Baumgartner, 1998). The non-restricted model for all dimensions yielded a good fit to data $\left(X^{2}=250.086\right.$, $\mathrm{df}=110, \mathrm{p}<0.001, \mathrm{RMSEA}=0.051, \mathrm{CFI}=0.961$, and $\mathrm{TLI}=0.944)$. Configural invariance was supported, since satisfactory levels of fit for the comparative fit index (CFI) and Tucker-Lewis index (TLI), and root mean square error of approximation (RMSEA) were achieved (Hu \& Bentler, 1995). Later, the full metric invariance model was 
estimated by constraining factor loadings to be equal across both groups. The results of a Chi-square difference test between the non-restricted model and the full-metric invariance model for each construct showed that full metric invariance was supported for both groups $\left(X^{2}=273.016, d f=117, p<0.001, R M S E A=0.051, C F I\right.$ $=0.958$, and $T L I=0.944)$, although we found a decrease in model fit. Following Hair et al. (1998), if imposing this constraint does not significantly increase model fit - CFI decreased from 0.961 to 0.958 - then measurement model invariance can be assumed. Therefore, our findings provide strong evidence to support full metric invariance (Steenkamp \& Baumgartner, 1998). In addition, evidence of a good model fit, reliability, convergent validity, and discriminant validity indicates that the measurement model was appropriate to test the structural model.

\section{Analysis of the structural model}

Structural equation modeling was conducted to assess the statistical significance of the relationships we propose to exist between store brand purchase intention and its dimensions (Figure 1). Model fit criteria suggested by Hu and Bentler (1995) were used for both measurement and structural model: $X^{2} / d f$, goodness of fit (GFI), adjusted goodness of fit (AGFI), comparative fit index (CFI), root mean square residual (RMR), and root mean square error of approximation (RMSEA). Acceptable models should have $\mathrm{X}^{2} / \mathrm{df} \leq$ 3, AGFI $\geq 0.80, R M R \leq 0.1, R M S E A \leq 1.0$, and $G F I$ and $C F I$ higher than 0.90. All of the obtained fit measures indicated that the structural model was acceptable $\left(X^{2} / d f=1.677 ; p<0.000\right)$ : $R M S E A=0.043$; $\mathrm{RMR}=0.061 ; \mathrm{GFI}=0.898 ; \mathrm{AGFI}=0.855 ; \mathrm{CFI}=0.957$ ) (Table 5 ).

Table 5. Structural modeling adjustment indexes

\begin{tabular}{|c|c|c|c|c|c|c|c|c|c|c|c|}
\hline \multicolumn{6}{|c|}{ Absolute fit measures } & \multicolumn{5}{|c|}{ Incremental fit measures } & \multirow{2}{*}{$\begin{array}{l}\text { Parsimony measures } \\
\text { Normed Chi-square }\end{array}$} \\
\hline Chi-square & $\mathrm{df}$ & $\mathrm{p}$ & $\mathrm{GFI}$ & RMSEA & RMR & AGFI & $\mathrm{NFI}$ & $\mathrm{IFI}$ & TLI & $\mathrm{CFI}$ & \\
\hline 250.086 & 110 & 0.001 & 0.930 & 0.051 & 0.049 & 0.884 & 0.934 & 0.961 & 0.944 & 0.961 & 2.328 \\
\hline
\end{tabular}

\section{Analysis of the differences between the two types of store brands}

The present study conducts a multi-group analysis to examine the differences between store brands with a manufacturer signature and store brands with no manufacturer signature. Group comparisons were made between store brands with manufacturer identification and store brands with no information regarding the manufacturer subsamples, using structural equation modeling.

Comparing the standardized coefficients obtained, the following results should be highlighted (Table 6). The results obtained report different results for both types of store brands. Firstly, we found that the variable with highest impact on consumers' purchase intention was store brand loyalty for brands with a manufacturer signature $\left(\beta_{56}=0.539^{* *}\right)$ and store brand image for brands without a manufacturer identification $\left(\beta_{36 \mathrm{~N}}=0.492^{* \star}\right)$. Secondly, in terms of effect size, the variables that seem to contribute most to store brand purchase intention for brands with a manufacturer signature are store brand loyalty $\left(\beta_{56}=0.539^{\star \star}\right)$, followed by store social image $\left(\beta_{26}=0.537^{\star \star}\right)$, store brand perceived quality $\left(\beta_{46}=0.491^{\star *}\right)$, and store commercial image $\left(\beta_{16}=0.239^{\star *}\right)$. However, store brand loyalty showed no statistical significance on purchase intention $\left(\beta_{45}=0.105^{\mathrm{ns}}\right)$, as this relationship was in the expected direction, but failed to reach statistical significance. Finally, the evaluation of store brands without a manufacturer identification showed that the variable with highest influence on purchase intention was store brand image $\left(\beta_{36 \mathrm{~N}}=0.492^{\star \star}\right)$, followed by store commercial image $\left(\beta_{16 \mathrm{~N}}\right.$ $\left.=0.283^{\star \star}\right)$, and store social image $\left(\beta_{26 \mathrm{~N}}=0.212^{\star \star}\right)$, whereas no significant evidence was found for the relationship between store brand perceived quality and purchase intention $\left(\beta_{46 \mathrm{~N}}=0.076^{\mathrm{ns}}\right)$.

On the other hand, with regard to the antecedents of store brand purchase intention, it should be noted that all relationships of store commercial image with store brand image $\left(\beta_{13}=0.326^{\star \star}\right.$; $\left.\beta_{13 \mathrm{~N}}=0.312^{*}\right)$ and store brand perceived quality $\left(\beta_{14}=0.632^{\star *}\right.$; $\beta_{14 \mathrm{~N}}=0.457^{\star \star}$ ) are significantly positive for both types of store brand, showing a higher impact of store commercial image on store brand quality perception. In the same vein, regarding the impact of store social image, our findings highlight a positive significant relationship between this variable, store brand image $\left(\beta_{23}=0.676^{* *} ; \beta_{23 N}=0.848^{* \star}\right)$, and store brand perceived quality $\left(\beta_{24}=0.380^{\star *} ; \beta_{24 N}=0.483^{\star \star}\right)$ also for both types of store brand. Thus, it can be affirmed that the better and more favorable the store commercial and social image, the better the store brand image and quality perceived. Therefore, consumers rely on both store commercial and social images in order to reduce store brands' purchase risk, regardless of whether the manufacturer is identified or not on the product package.

Finally, when analyzing the influence of the antecedents on store brand loyalty, it should be noted that store brand image 
exerts a positive influence on customer loyalty both for store brands with a manufacturer signature $\left(\beta_{35}=0.688^{\star \star}\right)$ and store brands with no manufacturer identification $\left(\beta_{35 \mathrm{~N}}=0.583^{\star \star}\right)$. However, store brand perceived quality shows a positive significant influence on loyalty for store brands with no manufacturer signature $\left(\beta_{45 \mathrm{~N}}=0.215^{\star *}\right)$; while perceived quality showed no statistical significance for store brands with a manufacturer identification $\left(\beta_{45}=0.105^{\mathrm{ns}}\right)$. See Table 7 .

Table 6. Results of the structural model (standardized coefficients)

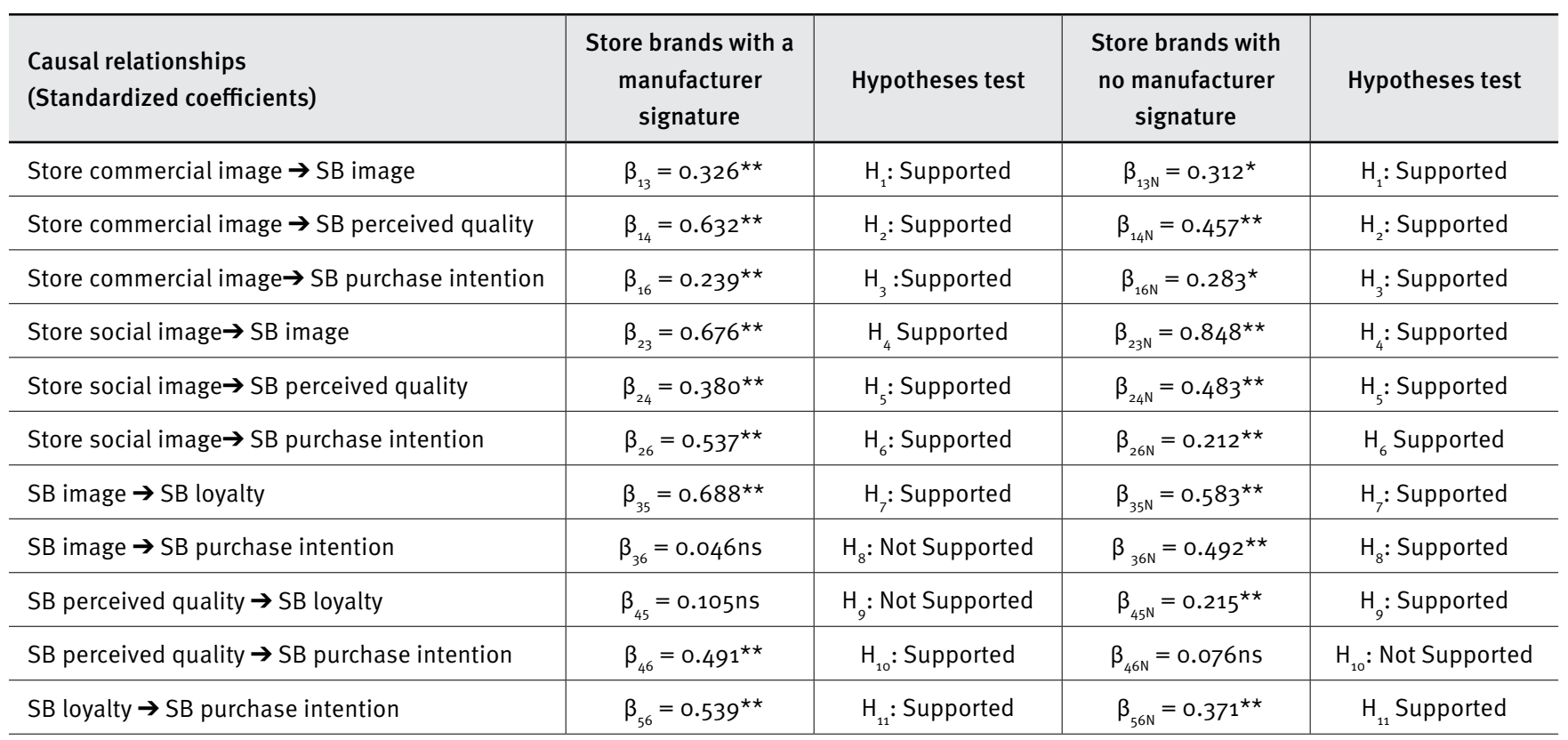

Note. ns=not significant

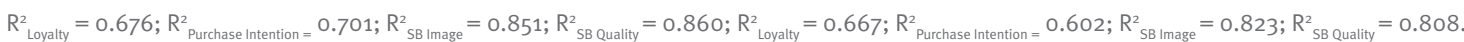

*significant $(p<0.1) ;{ }^{* *}$ significant $(p<0.05)$

The conceptual model proposed showed an adequate general fit to the provided data; and the parameters were tested to decide whether or not to accept the study's proposed hypotheses. With regard to store brands with a manufacturer signature, our results provide strong support for all research hypotheses, except for $\mathrm{H}_{8}$ and $\mathrm{H}_{9}$, thus not supporting a significant relationship between store brand image and purchase intention. The test of the hypotheses with store brands without a manufacturer signature highlights that ten of the eleven initial hypotheses are supported. More specifically, we found support for all the study's proposed hypotheses, except for $\mathrm{H}_{10}$, since our results did not confirm a significant relationship between store brands' perceived quality and purchase intention. Consequently, store brand loyalty and purchase intention were found to be significantly affected by store commercial and social image, store brand image, and perceived quality.

\section{The mediating role of store brand loyalty}

Our initial conceptual proposition is that loyalty mediates the effect of store brand image and store brand perceived quality on purchase intention. Following the procedure suggested by Baron and Kenny (1986), a mediating role exists when three conditions are satisfied. First, the independent variable has a significant effect on the mediator; second, the mediator has a significant effect on the dependent variable; and third, a previous significant relationship between the independent variable and the dependent variable is reduced after including the mediator. Moreover, when the effect of the independent variable is not statistically significant, a complete mediation takes place; otherwise, a partial mediation occurs.

As depicted in Table 6, with regard to brands with a manufacturer signature, significant relationships are observed between store brand image and loyalty $\left(\beta_{35}=0.688^{\star \star}\right)$, as well as between loyalty and purchase intention $\left(\beta_{56}=0.539^{\star \star}\right)$. Moreover, no significant link exists between store brand image and purchase intention $\left(\beta_{36}=0.046^{\mathrm{ns}}\right)$; thus, a complete mediation effect of store brand loyalty is supported. When analyzing whether loyalty mediates the effect of store brand perceived quality on purchase intention, we observe the lack of a significant effect of store brand quality on loyalty $\left(\beta_{46 \mathrm{~N}}=\right.$ $\left.0.105^{\mathrm{ns}}\right)$, thus not supporting a mediating effect. 
On the other hand, considering the store brands without a manufacturer signature, a significant link is observed between store brand perceived quality and loyalty $\left(\beta_{45 \mathrm{~N}}=\right.$ $\left.0.215^{\star *}\right)$, as well as between loyalty and purchase intention $\left(\beta_{56 \mathrm{~N}}=0.371^{\star \star}\right)$; nevertheless, perceived quality does not have a significant influence on purchase intention $\left(\beta_{46 \mathrm{~N}}=0.076^{\mathrm{ns}}\right)$, which demonstrates a complete mediation. Finally, we observe a significant influence of store brand image on loyalty $\left(\beta_{35 \mathrm{~N}}=\right.$ $\left.0.583^{* \star}\right)$, along with a statistically significant effect of loyalty on purchase intention $\left(\beta_{56 \mathrm{~N}}=0.371^{\star *}\right)$, while the link between store brand image and purchase intention is reduced after the inclusion of the mediator $\left(\beta_{56 \mathrm{~N}}=0.492^{* *}\right)$ for brands with no manufacturer signature. Therefore, according to Baron and Kenny (1986), the partial mediation of loyalty is supported.

\section{DISCUSSION}

There are many articles on store brands, although not many focus on comparing different types of store brands and on analyzing the role of the manufacturer identification on the product package, or the role of the manufacturer signature. The present paper aims to contribute to fill this gap in the literature by analyzing the variables influencing store brands' purchasing likelihood and the differences between store brands with and without a manufacturer identification. Our findings indicate that the presence of the manufacturer signature or identification on the store brand is not a determinant variable in the formation of store brand loyalty and purchase intention; consequently, these outcomes show a similar formation pattern for both types of store brand analyzed. That is, store brands with a manufacturer signature and store brands without one have similar sources in the formation of loyalty and purchase intention.

With regard to our main research question: "What are the influences of store and brand image on customers' loyalty and purchase intention for store brands with a manufacturer signature and store brands without a manufacturer signature?". The answer is "store brand image is the main variable influencing customer loyalty, while store social image and store brand image exert the highest impact on purchase intention both for store brands with a manufacturer signature and brands without a manufacturer identification". Consequently, one major finding is that we demonstrate image variables - linked both to store and store brand - to be strong predictors of store brand loyalty and purchase intention. Likewise, we can affirm that store brand image is the most important driver for store brand loyalty and purchase intention, for both types of store brand analyzed. Thus, store brand image, and, more specifically, the positive and favorable associations of a store brand, are critical to a store brand's success in today's increasingly competitive marketplace (Choi \& Huddleston, 2013). These results are in line with those of Netemeyer et al. (2004), who demonstrated store image to be a key variable on brands' purchase intention, and with those of Bao et al. (2011), who affirmed that consumers would be highly confident in the signaling ability of a store's image. Moreover, our findings show the positive influence of store commercial image both on store brand image and on store brand perceived quality for both types of brand analyzed, which is in line with the findings of Beristain and Zorrilla (2011). Therefore, good store image can help to increase customer loyalty and purchase intention, compensating retailers' efforts to offer a positive, favorable store image. A store's image could thus be reinforced by the launching of marketing activities and programs to enhance consumers' associations with the store. Our findings highlight that the store can take advantage of the impact of its image in terms of increasing loyalty and purchase intention.

In addition, our findings highlight some differences between the two types of store brand analyzed. The main differences are the lack of influence of store brand perceived quality on loyalty for products with a manufacturer signature, and the lack of influence of perceived quality on purchase intention for brands without a manufacturer identification. Consequently, it is worth stressing the low importance of store brands' perceived quality, as we did not find a significant impact of store brand quality perception on either store brand loyalty or purchase intention. These results are not consistent with previous studies that hold that store brand loyalty was characterized by attitudes elicited from sources such as perceived quality (Pappu et al., 2005). This may be because, nowadays, store brands are positioning themselves as a samequality alternative to manufacturer brands (Choi \& Huddleston, 2013). In addition, store brands now compete on a more equal footing with manufacturer brands in terms of product quality, and consumers perceive store brand quality to have improved (Grunert et al., 2006). Moreover, a few relevant differences between these two types of store brand should be highlighted. One major finding is the slightly higher influence of store commercial image for store brands with a manufacturer signature, whereas store social image shows a slightly higher influence for store brands without a manufacturer signature. Therefore, consumers may perceive store brands of retailers with a favorable commercial and social image as reliable and trustworthy (Ambler, 1997).

Another major finding of the study is that manufacturer identification in store brands is not a key determining factor of customer behavior. In this respect, we can propose that the creation of store brand loyalty and purchase intention - through store image and store brand image - shows a similar pattern for both 
types of brand, as consumers similarly perceive and evaluate store brand products regardless of information about the manufacturer. Therefore, despite assumptions that consumers generally perceive a store brand associated with a manufacturer as a guarantee and a quality offer (Dubois \& Duquesne, 1995), our results do not support significant differences on the variables influencing store brand loyalty and purchase intention. We hypothesized that the manufacturer signature would strongly influence the formation of store brand purchase intention, but this was not the case. One possible explanation would be that consumers rely on store brand image and on store image in their purchase decision process.

Finally, our findings demonstrate that store brand loyalty plays a mediating role between store brand image and purchase intention for store brands with a manufacturer signature; on the other hand, we found a complete mediating effect of loyalty between store brand perceived quality and purchase intention, and a partial one between store brand image and purchase intention for brands without a manufacturer identification.

\section{Managerial implications}

Based on our findings, we propose a few useful insights for retailers. Firstly, our findings recognize that consumers use the store brand image dimension as an important cue, influencing their loyalty and purchase intention. In order for this image to be effectively transmitted, communication actions conveying proximity to customers, credibility, and innovation should be conducted, as well as store brand image improvement programs. For example, retailers should increase consumers' exposure to their brands, both inside and out of points of sale. In terms of actions that may be conducted in the store, merchandising actions and a good store brand display should be considered. With regard to out-of-store actions, retailers should strongly invest on advertising. Secondly, and considering the importance of stores' both social and commercial images, retail managers should create effective advertising campaigns to clearly communicate what the company stands for to its customers. Retailers should actively communicate the quality of their store brands to consumers through in-store information, public relations campaigns, and advertising (Manzur et al., 2011).

\section{Research limitations}

The present study has several limitations that also provide venues for future research. With regard to the study's main limitation, firstly, it should be noted that it was carried out in Spain with a limited number of store brands. This factor can limit the generalizability of our results to other countries; therefore, we encourage future research to proceed in this direction by undertaking cross-cultural studies. Secondly, our study has analyzed a number of dimensions proposed in prior literature, which only represent a small part of all dimensions affecting store brand purchase intention. Therefore, other variables included in previous studies should be considered for the conceptual models in future research, such as price consciousness, price perception, purchase perceived risk, and even the product category. In this respect, a few authors have demonstrated that store brand purchase likelihood can depend on the product category considered (Batra \& Sinha, 2000). Therefore, our study focused on, and conducted its tests in, the context of large retailing in one single country, so caution must be exercised in generalizing from our findings, and further research is necessary to overcome these limitations.

\section{REFERENCES}

Aaker, D. A. (1991). Managing brand equity capitalizing on the value of brand name. New York: The Free Press.

Ailawadi, K. L., \& Keller, K. L. (2004). Understanding retail branding: Conceptual insights and research priorities. Journal of Retailing, 80(4), 331-342. doi:10.1016/j.jretai.2004.10.008

Ailawadi, K. L., Pauwels, K., \& Steenkamp, J.-B. (2008). Private label use and store loyalty. Journal of Marketing, 72(6), 19-30. doi:10.1509/ jmkg.72.6.19

Ambler, T. (1997). How much of brand equity is explained by trust?. ManagementDecision, 35(4), 283-292. doi:10.1108/00251749710169666

Anderson, J. C., \& Gerbing, D. W. (1988). Structural equation modeling in practice: A review and recommended two-step approach. Psychological Bulletin, 103(3), 411-423. doi:10.1037/0033-2909.103.3.411

Anselmsson, J., Johansson, U., \& Persson, N. (2007). Understanding price premium for grocery products: A conceptual model of customer-based brand equity. Journal of Product \& Brand Management, 16(6), 401-414. doi:10.1108/10610420710823762

Bagozzi, R. P., \& Yi, Y. (1988). On the evaluation of structural equation models. Journal of the Academy of Marketing Science, 16(1), 74-94. doi:10.1007/bfo2723327

Baltas, G. (1997). Determinants of store brand choice: A behavioral analysis. Journal of Product \& Brand Management, 6(5), 315-324. doi:10.1108/10610429710179480

Bao, Y., Bao, Y., \& Sheng, S. (2011). Motivating purchase of private brands: Effects of store image, product signatureness and, quality variation. Journal of Business Research, 64(2), 220-226. doi:10.1016/j.jbusres.2010.02.007

Bao, Y., Sheng, S., Bao, Y., \& Stewart, D. (2011). Assessing quality perception of private labels: Intransient cues and consumer characteristics. Journal of Consumer Marketing, 28(6), 448-458. doi:10.1108/07363761111165967

Baron, R. M., \& Kenny, D. A. (1986). The moderator-mediator variable distinction in social psychological research: Conceptual, strategic, and statistical considerations. Journal of Personality and Social Psychology, 51(6), 1173-1182. doi:10.1037/0022-3514.51.6.1173 
Batra, R., \& Sinha, I. (2000). Consumer-level factors moderating the success of private label brands. Journal of Retailing, 76(2), 175-191. doi:10.1016/s0022-4359(0o)00027-0

Beristain, J. J., \& Zorrilla, P. (2011). The relationship between store image and store brand equity: A conceptual framework and evidence from hypermarkets. Journal of Retailing and Consumer Services, 18(6), 562-574. doi:10.1016/j.jretconser.2011.08.005

Brown, J. T., \& Dacing, P. A. (1997). The company and the product: Corporate associations and consumer product responses. Journal of Marketing, 61(1), 68-84.

Choi, L., \& Huddleston, P. (2013). The effect of retailer private brands on consumer-based retailer equity: Comparison of named private brands and generic private brands. The International Review of Retail, Distribution and Consumer Research, 24(1), 59-78. doi:10.1080/095 93969.2013.821417

Chowdhury, J., Reardon, J., \& Srivastava, R. (1998). Alternative modes of measuring store image: An empirical assessment of structured versus unstructured measures. Journal of Marketing Theory and Practice, $6(2), 72-87$.

Collins-Dodd, C., \& Lindley, T. (2003). Store brands and retail differentiation: The influence of store image and store brand attitude on store own brand perceptions. Journal of Retailing and Consumer Services, 10(6), 345-352. doi:10.1016/Sog69-6989(02)00054-1

Corstjens, M., \& Lal, R. (2000). Building store loyalty through store brands. Journal of Marketing Research, 37(3), 281-291. doi:10.1509/ jmkr.37.3.281.18781

Devlin, D., Birtwistle, G., \& Macedo, N. (2003). Food retail positioning strategy: A means-end chain analysis. British Food Journal, 105(9), 653-670. doi:10.1108/00070700310497372

Diallo, M. F. (2012). Effects of store image and store brand price-image on store brand purchase intention: Application to an emerging market. Journal of Retailing and Consumer Services, 19(3), 360-367. doi:10.1016/j.jretconser.2012.03.010

Dick, A., \& Basu, K. (1994). Customer loyalty: Toward an integrated conceptual framework. Journal of the Academy of Marketing Science, 22(2), 99-113. doi:10.1177/0092070394222001

Doods, W., Monroe, K., \& Grewall, D. (1991). Effects on price, brand and store information on buyers' product evaluations. Journal of Marketing Research, 28(3), 307-319. doi:10.2307/3172866

Dubois, B., \& Duquesne, P. (1995). Essentiel pour comprende la valeur des marques: La force de conviction. Revue Française du Marketing, 2, 23-34.

Fornell, C., \& Larcker, D. (1981). Evaluating structural equation models with unobservable variables and measurement error. Journal of Marketing Research, 18(1), 30-50.doi:10.2307/3151312

Grewal, D., \& Levy, M. (2009). Emerging issues in retailing research. Journal of Retailing, 85(4), 522-526. doi:10.1016/j.jretai.2009.09.007

Grewal, D., Krishnan, R., Baker, J., \& Borin, N. (1998). The effect of store name, brand name and price discounts on consumers' evaluations and purchase intentions. Journal of Retailing, 74(3), 331-352. doi:10.1016/So022-4359(99)80099-2

Grunert, K., Esbjerg, L., Bech-Larsen, T., Brunsø, K., \& Juhl, H. J., (2006). Consumer preferences for retailer brand architectures: results from a conjoint study, International Journal of Retail \& Distribution Management, 34 (8) $597-608$.

Hair, J. F., Anderson, R. E., Tatham, R. L., \& Black, W. C. (1998). Multivariate data analysis. Saddle River, NJ: Prentice-Hall.
Hair, J. F., Anderson, R. E., Tatham, R. L., \& Black, W. C (1999). Analisis multivariante. Madrid: Prentice Hall.

Handelman, J., \& Arnold. S. (1999). The role of marketing actions with a social dimension: Appeals to the institutional environment. Journal of Marketing, 63(3), 33-48. doi:10.2307/1251774

Hartman, K. B., \& Spiro, R. L. (2005). Recapturing store image in customer-based store equity: A construct conceptualization. Journal of Business Research, 58(8), 1112-1120. doi:10.1016/j.jbusres.2004.01.008

Higgins, R. B., \& Bannister, D. (1992). How corporate commnications of strategy affects share price. Long Range Planning, 25(3), 27-35. doi:10.1016/0024-6301(92)90366-a

Hoch, S. J., \& Banerji, S. (1993, Summer). When do private labels succeed?. Sloan Management Review. Retrieved from http://sloanreview.mit.edu/article/when-do-private-labels-succeed/

Hu, L., \& Bentler, P. M. (1995). Evaluating model fit. In R. H. Hoyle. (Ed.), Structural Equation Modeling: Concepts, Issues And Applications. Thousand Oaks, CA: Sage.

Huang, Y., \& Huddleston, P. (2009). Retailer premium own-brands: Creating customer loyalty through own-brand products advantage. International Journal of Retail and Distribution Management, 37(11), 975-992. doi:10.1108/09590550910999389

Inman, J. J., Shankar, V., \& Ferraro, R. (2004). The roles of channel-category associations and geodemographics in channel patronage. Journal of Marketing, 68(2), 51-71.

Jacoby, J. (1971). A model of multi-brand loyalty. Journal of Advertising Research, 11, 25-31.

Jin B., \& Suh Y. G. (2005). Integrating effect of consumer perception factors in predicting private brand purchase in a Korean discount store context. Journal of Consumer Marketing, 22(2), 62-71. doi:10.1108/07363760510589226

Kantar World Panel. (2012). Worldpanel Distribución. Retrieved from http://www.kantarworldpanel.com

Karry, S., \& Zaccour, G. (2006). Could co-up advertising be a manufacturer's counterstrategy to store brands?. Journal of Business Research, 59(9), 1008-1015. doi:10.1016/j.jbusres.2006.05.002

Keller, K. L., \& Aaker, D. A. (1992). The effects of sequential introduction of brand extensions. Journal of Marketing Research, 29(1), 35-50. doi:10.2307/3172491

Kumar, N., \& Steenkamp, J-B. (2007). Private label strategy: How to meet the store brand challenge, Harvard Business Press

Liljander, V., Polsa, P., \& Riel, A. Van (2009). Modelling consumer responses to an apparel store brand: Store image as a risk reducer. Journal of Retailing and Consumer Services, 16(4), 281-290. doi:10.1016/j.jretconser.2009.02.005

Manzur, E., Olavarrieta, S., Hidalgo, P., Farías, P., \& Uribe, R. (2011). Store brand and national brand promotion attitudes antecedents. Journal of Business Research, 64(3), 286-291. doi:10.1016/j.jbusres.2009.11.014

Martos-Partal, M., \& González-Benito, O. (2011). Store brand and store loyalty: The moderating role of store brand positioning. Marketing Letters, 22(3), 297-313. doi:10.1007/s11002-010-9126-x

Myers, C. A. (2003). Managing brand equity: A look at the impact of attributes. Journal of Product and Brand Management, 12(1), 39-51. doi:10.1108/10610420310463126 
Netemeyer, R., Krishnan, B., Pullig, C., Wang, G., Yagci, M., Dean, D., ... Wirth, F. (2004). Developing and validating measures of facets of customer-based brand equity. Journal of Business Research, 57(2), 209-224.

Oliver, L. (1999). Whence consumer loyalty? Journal of Marketing, 63, 33-44. doi:10.2307/1252099

Pappu, R., Quester, P. G., \& Cooksey, R. W. (2005).Consumer-based brand equity: Improving the measurement-empirical evidence. Journal of Product \& Brand Management, 14(3), 143-154. doi:10.1108/10610420510601012

Richardson, P., Jain, A. K., \& Dick, A. S. (1996). Household store brand proneness: A framework. Journal of Retailing, 72(2), 159-185. doi:10.1016/So022-4359(96)90012-3

Satorra, A., \& Bentler, P. M. (2001). A scaled difference chi-square test statistic For moment structure analysis. Psychometrika, 66(4), 507514. doi:10.1007/bfo2296192

Semeijn, J., Riel, A. C. Van, \& Ambrosini, A. B. (2004). Consumer evaluations of store brands: Effects of store image and product attributes. Journal of Retailing and Consumer Services, 11(4), 247-258. doi:10.1016/So969-6989(03)00051-1

Schmidt, K. (1995). The quest for identity: Corporate identity, strategies, methods and examples. London: Casell.

Steenkamp, E. M., \& Baumgartner, H. (1998). Assessing measurement invariance in cross-national consumer research. Journal of Consumer Research, 25(1), 78-107. doi:10.1086/209528

Steenkamp, J.-B., \& Dekimpe, M. (1997). The increasing power of store brands: Building loyalty and market share. Long Range Planning, 30(6), 917-930. doi:10.1016/s0024-6301(97)00077-0
Steenkamp, E. M., \& Trijp, C. M. Van. (1991). The use of LISREL in validating marketing constructs. International Journal of Research in Marketing, 8(4), 283-299. doi:10.1016/0167-8116(91)90027-5

Sudhir, K., \& Talukdar, D. (2004). Does store brand patronage improve store patronage? Review of Industrial Organization, 24(2), 143-160. doi:10.1023/b:reio.0000033353.52208.ba

Turban, D. B., \& Greening, D. W. (1996). Corporate social performance and organizational attractiveness to prospective employees. Academy of Management Journal, 40(3), 658-672.

Vahie, A., \& Paswan, A. (2006). Private label brand image: Its relationship with store image and national brand. International Journal of Retail \& Distribution Management, 34(1), 67-84. doi:10.1108/09590550610642828

Yoo, B., Donthu, N., \& Lee, S. (2000). An examination of selected marketing mix elements and brand equity. Journal of the Academy of Marketing Science, 28(2), 195-211. doi:10.1177/0092070300282002

Yu, W., \& Ramanathan, R. (2012). Retail service quality, corporate image and behavioural intentions: The mediating effects of customer satisfaction. The International Review of Retail, Distribution and Consumer Research, 22(5), 485-505. doi:10.1080/09593969.2012.711250

Zeithaml, V. A. (1988). Consumer perceptions of price, quality and value: A means-end model and synthesis of evidence. Journal of Marketing, 52(3), 2-22. doi:10.2307/1251446

Zimmer, M. R., \& Golden, L. L. (1988). Impressions of retail stores: A content analysis of consumer images. Journal of Retailing, 64(3), 265-293. 